\title{
A Law of Social Development
}

\author{
Igor Varyash
}

Doctor of in Economics, Head of the Analytical Centre for Financial Research, Research Financial Institute of the Ministry of Finance of the Russian Federation, Moscow, Russia

varjas@nifi.ru

\section{Abstract}

Changes in the amount, structure and composition of the information factors point to future changes in a society. This makes it possible to formulate a hypothesis or a law of information impact on a society: increase of information speeds social development, and vice versa, a decrease of information inhibits it. A consequence of what can be called a sociological law of information is that an index of increase/decrease of the amount of information points to the changing direction of social developments, and especially to the turning points in seemingly stable trends. In this article, the above-mentioned conclusion is discussed on the basis of sociopolitical and financial and economic data.

Keywords: time; politics; economics; information; society

JEL Classification: D89, 010

$\mathrm{T}$ he preservation of the volume of information or the size of the information space does not mean that there was no change in the amount of information available. For example, as soon as banks go into liquidation, and it becomes meaningless to these to position themselves in the financial information space, their participation turns into a burden for information space because these create data smog that replaces the actual information. At present, this situation is not purely theoretical as a number of financial organizations continue to act in information space although their main activity is suspended. Furthermore, examples from the history of the Central Bank point to the same direction. The most striking example is the information lull before the 1998 Russian default. In particular, during the course of 1998 the flow of information was slowly drying up, and not only that flowing from the Central bank to the bank system, but also the flows of information generated within the financial market, namely, in the segments of the state short-term bonds and inter-bank loans. The monitoring of bank policy by the Russian Central bank was also influenced by the collapse of information.

The same can be illustrated by the contemporary information war, which takes place be- tween business and political elites in the US. It is possible that the US President slightly exaggerated the role and significance of data smog created in media space by newsmakers engaged by his political opponents, as well as by analysts and commentators, but the fact is that society is divided in its attitude to various things including the interpretation of this information. Each side sees the information provided by mass media as false and this leads to mounting risks of dangerous social and political instability.

Similar, although the less visible effect of the shrinking information space reveals itself in the activities of international organizations, which signals about the risk of growing international tensions. This, in the 2010s, information provided by international financial organizations, first of all, by the International Monetary Fund, decreased: the sample of periods in published prognoses was narrowed, only annual information was published, and quarterly data was dropped. This trend was compensated through the Organisation for Economic Co-operation and Development (OECD), MARKit Economics, as well as by international newsagents Thomson Reuters and Bloomberg by launching of leading indicators and consensusprognoses on the quarterly and monthly level. But these agencies also began to wrap up the open 
publication of data ${ }^{1}$. It is not difficult to see that this preceded the sharp increase of international economic and political conflicts.

The speed of socio-economic processes depends directly on the increase of information and, to a certain extent, can even be measured by this increase. The change of information space, which reached a certain speed, is especially sensitive to attempts to curtail it forcefully. In mass conscience, defamation is used, but this is not possible in professional communities; thus, in those fields, other means are applied - either political persecution of the bearers of knowledge or the promotion of pseudo-science. Unfortunately, there are plenty of examples. Recently history is being re-written again for propaganda purposes, and attempts have been made to found "econophysics", which attracted public attention, etc. This quasiscientific grey data smog, together with obvious distortions of the idea of the search for plagiarism in academic disciplines lowers the prestige

\footnotetext{
${ }^{1}$ This phenomenon, which is relatively new, at least, in its scale, also emerged in Russian post-reform practice of monetary authorities. In the early 1990s, the Central Bank staff was of the opinion that crediting bodies could not have policies of their own. This opinion was voiced at the discussion of the programme of the monitoring of bank policy; its opponents appealed to a seemingly waterproof argument that commercial credit organizations lacked independent bank policy as opposed to a real monetary and credit policy of the Central Bank. It was stated, with no justification, that tool of monitoring was all nonsense because it did not look like bank statistics, and that banks would not report anything about their work. What the Central Bank wanted to know about the banks' policies - first of all, about currency policy, crediting policy, and the policy in the market of the state short-term bonds was proclaimed unknowable because it was assumed that commercial banks had not and could not have any independent policies; in other words, it was implied that commercial credit organizations only followed the orders from the Central Bank, as it had happened, and thought to had happened, in the system of the state Bank of the USSR. Indeed, at that time, a chance for banks to deviate from the policy of the Central bank seemed negligible. The fate of monitoring remained unclear until the first poll took place. It demonstrated the need for a new communication channel between the regulator and the community of banks, important for the emerging two-tier bank system. About a year and a half after monitoring, the Russian Agricultural bank and the Incombank (two well-known and relatively large banks of the time) refused to participate in it. This was a danger signal, which could have been viewed as a risk of lowering level of information exchange within the bank system. Soon it emerged, that the said banks left the system of information exchange because by that time were, in fact, bankrupt. We will not go into the causes of the sharp decline of their financial health, and will only remark that the decrease of information flow proved to be very sensitive to the first signs of the crisis of the Russian bank system, which developed in
} the default of 1998. of science and serves as an indirect justification for less investment into science and education, which, in the end, slows the social development.

There is as much information in the world as there has been produced. The danger of spreading of false information is that it distorts its real impact on the society, thus creating a deformation in its development. As soon as disinformation emerges in a society, unrecognizable risks grow. The addition of true information lessens risks (this is one underestimated tool for risk management), and, indeed, shrinking of real information increases risks.

One can only guess to what extent the authorities act consciously by implementing the policy of the "sterilization of information". One should bear in mind, however, that all monetary reforms in the USSR and Russia were linked to both shrinking of information and defamation. Moreover, the history of modern wars saw false banknotes (money also provides information) as a dangerous weapon that could create chaos in national economies that already suffered from serious and sometimes fatal overload. Today, there is a heated debate about the interference of states in the world market of crypto-currencies, which are nothing but electronic information about money, but not the money itself.

Information holds an important component, and this is a mostly coded reference to future events. The even historical information contains the said component because it had been produced to know the future. The change in volume and structure of information, and in the composition of information factors point to future changes in the society. A striking example of this is a current turbulent political life in the US where false information replaces the real one, thus increasing risks of social instability considerably, not recognized by American elites.

Two examples mentioned above - financial information and information provided by mass media - do not exhaust the problem of the changes in its parameters seen as indicators for the early detection of system crises of the society. Other information flows are equally important - i.e., those produced in the intellectual sphere - in education, culture, finance, media, consulting. This aspect is now pushed into the background by problems of safety, survival and ecology. However, its actuality grows as it is being accepted as the 
main driver of social development, which plays a core role in the new economic model of the economy of knowledge. With the rise of sociopolitical activism in the world, the role of social studies in education grows as well. The neglect of social studies, which in the past had been reduced to the propaganda of either "communism", or the "consumerist society", is the thing of the past.

\section{Insertion}

The characteristic of intellectual production is in its "natural" quality of self-growth, both literally, expressed in the increase of information space, and economically, shown in the self-growth of the price of intellectual resources (intellectual property). Moreover, information cannot be multiplied if it does not grow, in other words, the translation of "knowledge" is based on its ability to self-grow. To put it simply, the news is needed, and this is a basis for the media industry. Knowledge cannot be old; thus, it can only be new. This is the cornerstone of science. In a sense, the same can be said about art, which lives in the renewal of forms, meanings and aesthetics, and this is demonstrated in the fashion industry. Let us add that, unlike naturals sciences where the object of physical world is relatively stable, at least, inhuman dimension (although even this postulate is being re-interpreted as a result of changes in physical condition of the Earth, which is happening in front of our eyes), in social sciences, the object - the society - evolves, thus creating a need for the corresponding development of new trends in academic studies ${ }^{2}$.

The ecology of information requires keeping policies transparent, and this concerns not only the authorities but social life as a whole. Lowering the level of transparency even in one of society's subsystems inevitably slows down all social development. The law of information for living systems is that a system is indifferent to any increase in information, but this does not apply to a more complex, social system where any decrease of information leads to its degradation, and vice versa, any increase of information determined its development. Studies in Economics have long confirmed that the rise of transparency is a necessary condition of the efficient policy. Clarity of aims and goals, programmes and controls - all of these in equal measure defined the efficiency of economic projects.

\footnotetext{
${ }^{2}$ Development is the way societies change, and it is revealed in laws of deepening social inequality, increasing social diversity and growing speed of social transformation.
}

Transparency is not just an idea, but a technology, which is reflected in corresponding internationally recognized demands to the actions of authorities, corporations and professional market players. American monetary authorities led the way in developing requirements to the disclosure of information, organization of the circulation of information within the code of corporate management, code of ethical market behaviour, international standards of reports, etc. Introduction of these technologies was necessary to provide for the US currency board, and not only for that, the state ensures access to business information for investors, regulators and law enforcers.

Development is connected to the increase of information because each innovation requires not only relevant information but maximum information. This condition is of great importance because it is difficult to say in advance, which of bits of information would dominate later, and which would be pushed to the background. One of the most obvious examples here is military technologies. These change quickly, and what seemed yesterday to cause unacceptable damage to the enemy, would become surpassed tomorrow. This happened to nuclear and conventional weapons, which are now being successfully supplanted by technologies of hybrid wars; this happened to words wars now replaced by local conflicts.

Another important aspect of this topic is that the volume of information is rising dynamically, and today it is not possible for one person even to comprehend, let alone process it, but even to comprehend it. Information can only be processed by formal and/or informal partnerships, through the use of the endless resource of the "collective consciousness" when information exchanges happen both on the verbal and descriptive level, and on subconscious one. From this point of view, it becomes clear the distortion of information space leads to unmanageability, and as a consequence, to slowing development.

No less, and perhaps even more important is the demand for maximum information in academic studies because it is not possible to produce new knowledge without correlating it to the existing one. Thus, academic disciplines tend to narrow research focus and to produce new knowledge at the overlapping margins of various academic subjects, fields and even disciplines. 


\section{Insertion}

Adaptation of the Russian educational system to the requirements of Western universities (the so-called Bologna system) deforms information space on the lowest levels of professional education by moving the acquisition of the fundamental knowledge component to further, more advanced staged. It would seem that there is some sense in this - to begin with practice-oriented studies, and then add world-view-shaping knowledge on top of this. The problem is, the practice-oriented education, is in fact, far from real professional practice, and only at M St level, a considerable number of students combine work and studies, to the detriment of the latter.

Both decrease and increase of information are natural for society, thus, it is important to understand how sensitive this system is to even slightest changes - distortion of information space of a market or corporate management, or of government's policies. It should be taken into consideration that there was an interesting phenomenon in the USSR: as soon as problems emerged in the economy, the bureaucratic system suddenly sprang to action, and normative acts followed by propaganda campaigns abounded. This was defamation intended to work as social anaesthetics for growing social tensions. Something similar happens now in the developed countries, which suffer from ethno- cultural shock caused by the arrival of migrants; these were pushed from their home countries by local conflicts provoked by the same Western countries to raise the competitiveness of their economies as these suffer from the rising cost of intellectual resources.

The above-said leads to the idea of the quantitate evaluation of the information dynamics, which would have pointed to an increase/ decrease of risks in a society. One possible method is the registration of information events. Thus, experiments with news lines made by subject-oriented business analytics have demonstrated their stable correlation to the expectation of professional market players. This would have been a trivial conclusion; however, it appeared that not only the changes in information space shape expectations but also the expectation of professional market players shape subject-oriented information space. Upon consideration, this can also be seen as trivial. What is far from trivial, however, is that in both cases stochastic correlation between corresponding times series is inconstant. It could have been accepted that news flow shapes expectations more often than not. In the latter case, it can be said that the model of the behaviour of market players change, as if time slows, while in the former case the time seems to congest.

\section{References}

Akerlof, G., \& Schiller R. (2010). Spiritus Animalis: or How human psychology drives the economy and why it matters for global capitalism [Spiritus Animalis, ili kak chelovecheskaya psikhologiya upravlyaet ekonomikoi i pochemu eto vazhno dlya mirovogo kapitalizma]. Trans. from English, A. Suvorov (ed.). Moscow: United Press. 273 p.

Chomitz, Ken. (2015). Information as intervention: A visit to Digital Green. Retrieved from http://blogs.worldbank.org/developmenttalk/information-intervention-visit-digital-green.

Deformation of social relations and communication. (2001). In: Social psychology. The textbook. A. N. Sukhov, A.A. Derkach, (eds.). Moscow: Izdatelэskii tsentr Akademiya. 600 p.

Evaluation of STI policies. (2012). In OECD Science, Technology and Industry Outlook 2012. OECD. Retrieved from https://www.oecd-ilibrary.org/science-and-technology/oecd-science-technology-and-industry-outlook-2012_sti_outlook-2012-en.

Hubiev R.K. (2009). Transparency of the company and its competitive significance [Transparentnost' kompanii i ee konkurentnoe znachenie]. Rossiiskoe predprinimatel'stvo, 10(8), 44-48.

Milner B. (1998). The trust factor in promoting economic reforms [Faktor doveriya pri provedenii ekonomicheskikh reform]. Voprosy ekonomiki, 4, 27.

Moiseev S. (2002). The policy of currency interventions of the Central banks: nature, the informal mechanisms and the effectiveness of the operations of the Bank of Russia [Politika valyutnykh interventsii tsentral'nykh bankov: sushchnost', tenevye mekhanizmy i effektivnost' operatsii Banka Rossii]. Finansy i kredit, 11, 46-53. 
Standard \& Poor's and CEFIR. (2008, November 13). The study of information transparency of Russian companies in 2008: modest progress against the background of a sharp decline in the number of IPOs [Issledovanie informatsionnoi prozrachnosti rossiiskikh kompanii v 2008 g.: Neznachitel'nyi progress na fone rezkogo snizheniya kolichestva IPO]. Retrieved from https://www.nes.ru/dataupload/files/science/6484.pdf.

Shannon, K. (1963). Works on information theory and Cybernetics [Raboty po teorii informatsii i kibernetike]. Trans from English. Moscow: Izdatel'stvo inostrannoi literatury. 830 p.

Sichakova E. (2000). Information openness of state bodies as a factor of influence on economic growth [Informatsionnaya otkrytost' gosudarstvennykh organov kak faktor vliyaniya na ekonomicheskii rost]. Problemy teorii i praktiki upravleniya, 3, 12.

Varyash I. Yu. (2012). Controlling expectations. Monograph [Kontrolling ozhidanii. Monografiya]. Moscow: Financial University under the Government of the Russian Federation. 173 p.

Varyash I. Yu., Shvandar K.V., Burova T.F. (2014). The actualization of macroeconomic forecasts in the budget process [Aktualizatsiya makroekonomicheskikh prognozov v byudzhetnom protsesse]. Finansovyj Zhurnal, 4, 118-128.

Webster F. (2004). Theories of the information society [Teorii informatsionnogo» obshchestva]. Trans. from English. Moscow: Aspect Press. 400 p.

\section{Закон социального развития}

Игорь Варьяш

Доктор экономических наук, руководитель Аналитического центра финансовых исследований Научноисследовательского финансового института Министерства финансов Российской Федерации, Москва, Россия

varjas@nifi.ru

Аннотация. Изменения в объеме, структуре и составе информационных факторов указывают на будущие изменения в обществе. Это дает возможность сформулировать гипотезу или закон информационного воздействия на общество: увеличение информации ускоряет социальное развитие, и наоборот, уменьшение информации тормозит его. По мнению автора, следствием того, что можно назвать социологическим законом информации, является то, что индекс увеличения/уменьшения объема информации указывает на изменение направления социальных событий, особенно, на поворотные точки при, казалось бы, устойчивых тенденциях социально-политического и финансовоэкономического развития страны.

Ключевые слова: время; политика; экономика; информация; общество; закон информационного воздействия; информационные факторы

JEL Classification: D89, 010 